Original Research Paper

\title{
Optimisation of Bromelain Enzyme Extraction from Pineapple (Ananas comosus) and Application in Process Industry
}

\author{
Resmi Mohan, Venkatasubramanian Sivakumar, \\ Thirumalaisamy Rangasamy and Chellappa Muralidharan \\ CSIR-Central Leather Research Institute (CLRI), \\ Council of Scientific and Industrial Research (CSIR), Adyar, Chennai-600 020, India
}

\author{
Article history \\ Received: 15-06-2016 \\ Revised: 16-08-2016 \\ Accepted: 18-08-2016 \\ Corresponding Author: \\ Venkatasubramanian \\ Sivakumar \\ CSIR-Central Leather Research \\ Institute (CLRI), Council of \\ Scientific and Industrial \\ Research (CSIR), Adyar, \\ Chennai-600 020, India \\ Email: vsiva1clri@gmail.com
}

\begin{abstract}
Bromelain is a general name for a family of sulfhydryl proteolytic enzymes obtained from Ananas comosus, the pineapple plant. The objective of the present study is to compare the activity of Bromelain from pineapple fruit and peel and to check the efficiency of this crude Bromelain enzyme in unhairing step in leather processing. The crude Bromelain was extracted and activity of enzyme was measured using tyrosine as standard and expressed in Units/mL of enzyme. The effect of preservatives such as sodium benzoate and sodium metabisulphite on the activity of the enzyme was studied for one week. The effect of pH (3-5) was studied using suitable $\mathrm{pH}$ buffer solutions. The kinetics of the proteolytic activity of the enzyme was studied using casein as substrate. It was found that the optimum $\mathrm{pH}$ of the crude extract was 4.5. In general enzyme activity got affected by the use of preservatives. The kinetic studies show that the activity of enzyme was increasing during initial period. The unhairing activity of crude extract of $\mathrm{pH} 4.5$ was also studied using cow hide pieces. After $24 \mathrm{~h}$ treatment with the extracted crude Bromelain enzyme, good unhairing efficacy was achieved for leather making.
\end{abstract}

Keywords: Bromelain, Enzyme, Fruit Peel, Pineapple, Unhairing

\section{Introduction}

Bromelain is the major protease enzyme present in the pineapple constituting an unusually complex mixture of protein digesting enzymes. It is present in stem, fruit, crown, core, leaves of pineapple. It is a mixture of different thiol endopeptidases, other components like phosphatases, glucosidase, peroxidases, cellulases, glycoproteins, carbohydrates, several protease inhibitors and organically bound calcium (Bhattacharyya, 2008). Some minor cysteine endopeptidases (ananain, comosain) are also present in the enzyme from pineapple stem. The enzyme extracted from the stem is called stem Bromelain (EC 3.4.22.32) and from fruit is called fruit Bromelain (EC 3.4.22.33) (Babu et al., 2008). It is made up of 212 amino acids and the molecular weight is $33 \mathrm{kDa}$ (Heinicke and Gortner, 1957; Murachi and Neuratii, 1960). Bromelain is inhibited by $\mathrm{Hg}^{++}, \mathrm{Ag}^{+}, \mathrm{Cu}^{++}$, antitrypsin, estatin $\mathrm{A}$ and $\mathrm{B}$, iodoacetate (Harrach et al., 1998). It exhibits a broad specificity for protein cleavage and stable in $\mathrm{pH} 3$ to 7 and temperature 40 to $60^{\circ} \mathrm{C}$ (Mohapatra et al., 2013).

Bromelain has been used widely in food, medical, pharmaceutical and cosmetic industries and other industries as well. In the food industry, it is used for meat tenderization, grain protein solubilization, beer clarification, baking cookies and protein hydrolysate production (Walsh, 2002). It was studied that pineapple juice was an effective enzymatic browning inhibitor in fresh apple slices (Lozano-de-Gonzales et al., 1993; Meza et al., 1995) and several important medical applications (Hale et al., 2005; Seltzer, 1964; Neubauer, 1961; Metzig et al., 1999; Batkin et al., 1988; Klaue et al., 1979; Hale et al., 2002; Livio et al., 1978; Renzini and Varego, 1972; Maurer, 2001).

Leather processing involves variety of chemicals (Ludvik, 1997; Ramasami, 2001) and generate considerable amount of pollution in leather processing. A considerable part of this is discharged into the effluent (Mariappan, 1997). In recent years, enzyme aided bioprocessing of leather provides potential alternative 
to chemical based processing (Sivakumar et al., 2012). Keeping in view of the wide use of Bromelain enzyme as applied in several other industries, the same could be employed in leather industry for potential benefits. Even though, several enzyme based works have been reported in leather processing, there is a need for exploring newer options such as plant based enzymes such as Bromelain.

Owing to the potential benefits of Bromelain enzyme which are efficient in nature, the same has been explored for leather application in the present study as first report. In the present work, crude extract of Bromelain was extracted from pineapple fruits and peels and studies were conducted on its activity at different $\mathrm{pH}$ and in the presence of preservatives. Also studies were conducted on its kinetics and stability of the enzyme. Since, Bromelain is a sulfhydryl proteolytic type of enzyme, which could be used in beam house operations in leather processing as well as other potential industrial applications. Hence, in the present work the capacity of crude extract of Bromelain on unhairing step in leather processing was also studied.

\section{Materials and Methods}

Pineapple fruit were purchased from the nearby fruit shop in Chennai and stored at $1{ }^{\circ} \mathrm{C}$. Sodium Acetate trihydrate, Sodium Benzoate, Trichloroacetic acid, Casein acc. to Hammarsten, Sodium bicarbonate, sodium metabisulphite were purchased from Sisco Research Laboratories Pvt. Ltd. Phosphate buffer pH-7 was purchased from S.D Fine Chem Limited. Sodium Carbonate and Sodium hydroxide were purchased from Merck specialities Private Limited and Himedia Laboratories Pvt. Ltd. The equipments used for the present study are Centrifuge (REMI), Magnetic stirrer, UV Visible spectrometer (Shimadzu Make) and Weighing balance.

\section{Crude Bromelain Enzyme Extraction}

Extraction and separation of Bromelain enzyme from the pineapple fruit material is essential. The pineapple fruit and peel were separated and cut into small pieces and was processed separately for the extraction of enzyme. Fruit pieces and peel were weighed and grinded in mortar and pestle to extract the juice. After extracting the juice, crude enzyme from the fruit remaining was further extracted by adding $20 \mathrm{~mL}$ distilled water was added to it. Then the juice was filtered using whatman filter paper $(150 \mathrm{~mm})$. The filtrate was centrifuged at $10,000 \mathrm{rpm}$ at $4^{\circ} \mathrm{C}$ for $10 \mathrm{~min}$ to remove insoluble materials. The supernatant was collected and stored at $4^{\circ} \mathrm{C}$ as shown in Fig. 1. It was used as crude extract of bromelain enzyme from pineapple fruit and peel.

\section{Enzyme Activity Test for the Crude Extract of} Bromelain

Determination of enzyme activity is essential for finding out the actual activity as well as for any application purpose. Activity of any enzyme can be assayed either by substrate utilization method or product formation method. The amount of tyrosine (product) liberated is a measure of the activity of the protease. In this assay, casein acts as a substrate. The protease digests casein and the amino acid tyrosine is liberated along with other amino acids and peptide fragments using experimental conditions with incubation period of 20 min. The amount of tyrosine released is quantifiable and measured as an absorbance value at $280 \mathrm{~nm}$ on the spectrophotometer. The more tyrosine that is released from casein, the stronger the activity of the protease. Absorbance values generated by the activity of the protease are compared to a standard curve, which is generated by reacting known quantities of tyrosine to correlate changes in absorbance with the amount of tyrosine in micromoles. Bromelain activity was expressed as units per $\mathrm{mL}(\mathrm{U} / \mathrm{mL})$. Tyrosine was used as a standard. One unit of protease activity is defined as 'that quantity of enzyme, which liberates amino acids and non precipitated peptides equivalent to $1 \mu \mathrm{g}$ of tyrosine per minute per $\mathrm{mL}$ under assay conditions. The assay of crude Bromelain extract was performed as below. Blank (B) is used for spectrometer with all the reagents other than enzyme and substrate. Reagent Blank (RB) is used to remove the reagent interference (such as unreacted enzyme and substrate) in the OD value. In RB all the reagents used in the assay will contain but the enzyme will not digest the casein because it is added after stopping the reaction by using TCA. In Reagent Mixture (RM) the substrate was added after adding enzyme. In this reaction between enzyme and substrate will take place. The enzyme assay was carried out as follows:

- $1 \mathrm{~mL}$ enzyme were added in the RM

- $1 \mathrm{~mL}$ of sodium acetate buffer was in RB, RM and B. The buffer will give optimum $\mathrm{pH}$ for the reaction of enzyme and substrate in RM

- After adding buffer, casein $1 \mathrm{~mL}$ was added in $\mathrm{RB}$ and RM

- Then distilled water was added in the B, RB and RM. The water will dilute the enzyme substrate complex to form product

- The RB, RM and B were kept for incubation of 20 min for the reaction to take place

- After incubation, $1 \mathrm{~mL}$ of TCA was added to stop the reaction and $1 \mathrm{~mL}$ of enzyme were added in the $\mathrm{RB}$

- Then after incubating for $10 \mathrm{~min}$ at $37^{\circ} \mathrm{C}$. centrifuged the samples at $10000 \mathrm{rpm}$ for $10 \mathrm{~min}$

- The supernatant solution was used for checking OD 


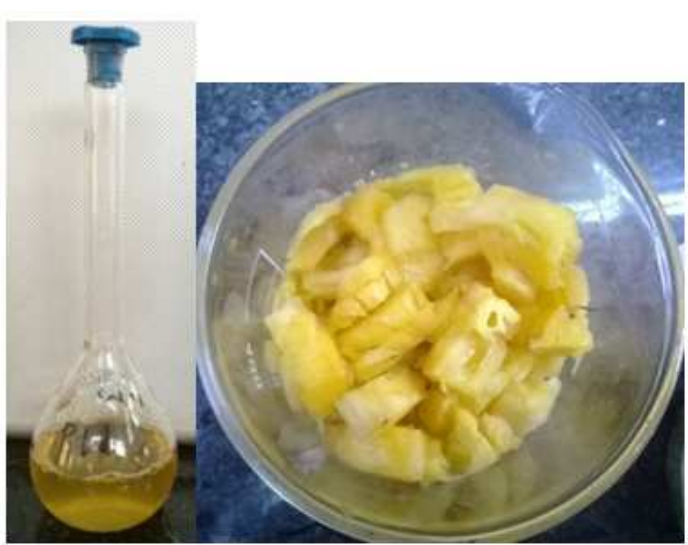

(a)

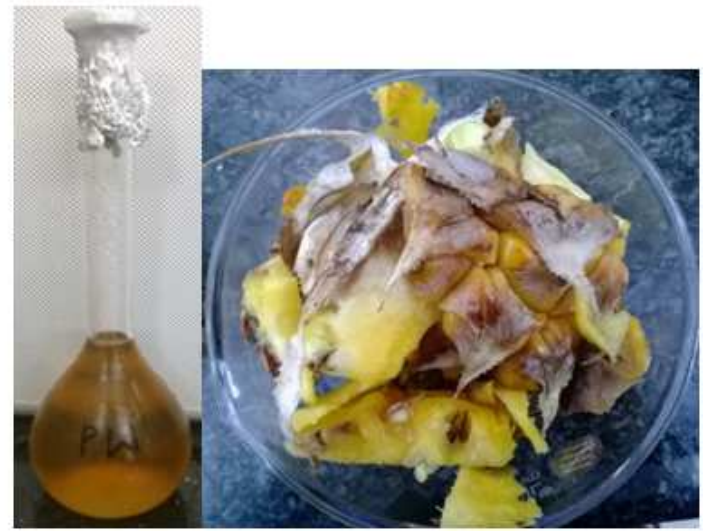

(b)

Fig. 1. Crude extract of Bromelain enzyme, (a): From pineapple fruit, (b): From pineapple peel

\section{Preparation of Standard Curve}

- $1 \mathrm{mg} \mathrm{mL}^{-1}$ of L-Tyrosine standard stock solution

It was prepared by adding $10 \mathrm{mg}$ of L-Tyrosine in $6 \mathrm{~mL}$ distilled water. Add $2 \mathrm{~N} \mathrm{NaOH}$ drop by drop at $40^{\circ} \mathrm{C}$ until the tyrosine dissolves with gentle stirring by using magnetic stirrer. After completely dissolving the tyrosine, make up the volume to $10 \mathrm{~mL}$ using distilled water. This solution will be diluted further to make our standard curve:

- Prepare 10 to $100 \mu \mathrm{g}$ of working solution by taking 10 to $100 \mu \mathrm{L}$ in a series of eppendorf tubes from tyrosine stock solution

- Make up the volume to $1500 \mu \mathrm{L}$ with distilled water in all eppendorf tubes

- Measure the absorbance of the supernatant at $280 \mathrm{~nm}$

- Plot a graph with tyrosine content $(\mu \mathrm{g} / \mathrm{mL})$ in the $\mathrm{x}$ axis and absorbance in $\mathrm{Y}$ axis to obtain a straight line

- Find the slope of the straight line

\section{Calculation of Enzyme Activity}

The activity of the Bromelain enzyme was calculated using the formula:

Units / $m L$ enzyme
$=\frac{(\mu \mathrm{g} / \mathrm{mL} \text { of tyrosine equivalents released }) \times \text { dilution factor }}{\text { Volume of enzyme used }(m L) \times \text { Time of assay }(\text { minutes })}$

$\mu \mathrm{g} / \mathrm{mL}$ of tyrosine equivalents released

= actual OD / slope of standard graph

Actual $O D=$ Reaction Mixture $O D$ - Reaction blank $O D$

\section{Effect of pH on Crude Bromelain Enzyme Extract}

Since any activity of enzyme is dependent on the $\mathrm{pH}$, it is essential to find out the $\mathrm{pH}$ at which the Bromelain enzyme is most active. The effect of $\mathrm{pH}$ on the activity of crude Bromelain enzyme was estimated by using casein as substrate following the procedure as explained earlier. The activity of crude Bromelain enzyme on casein was studied at various $\mathrm{pH}$ ranges, by using phosphate $(\mathrm{pH}-7)$, sodium acetate $(\mathrm{pH}-3.5,4,4.5,5)$ and sodium carbonate ( $\mathrm{pH}-9)$ buffers.

\section{Effect of Preservatives on the Activity of Crude Bromelain}

In the present study, we intend to use bromelian enzyme in crude form for our leather application due to higher cost of purification involved and subsequent commercial viability. Due to the degradable nature of the fruit material and enzyme, the use of suitable preservative in this regard would be beneficial. Hence, the effect of preservatives such as sodium benzoate and sodium metabisulphite on the activity of crude Bromelain enzyme was measured by using casein as substrate and $0.1 \mathrm{M}$ sodium acetate buffer ( $\mathrm{pH}-4.5$ ) are used for the assay. The preservatives are added at a concentration of $1 \mathrm{~g}$ per $\mathrm{kg}$ of fruit (Gautam et al., 2010). From $150 \mathrm{gm}$ of fruit the filtered juice was about $100 \mathrm{~mL}$. Then each $25 \mathrm{~mL}$ of filtered extract $0.05 \mathrm{gm}$ of sodium benzoate $(1 \%)$ and sodium metabisulphite was added and in other $25 \mathrm{~mL}$ of crude extract $0.025 \mathrm{~g}$ of sodium benzoate was added $(0.5 \%)$.

\section{Kinetic Studies}

It is very essential to find out the acivity of the enzyme with respect to time as kintetic study. Therefore, the activity of crude extract of Bromelain was studied after 10, 20, 30, 40, $50 \mathrm{~min}$ after incubation with substrate and also after 2 and $3 \mathrm{~h}$ after incubation. Sodium acetate buffer ( $\mathrm{pH}-4.5)$ was used for the assay. 


\section{Stability of the Crude Extract of Bromelain Enzyme}

The stability of the crude extract of Bromelain enzyme was also studied by assaying the activity of the crude extract in alternate days for 1 week. They are as follows:

a. Crude extract of Bromelain from fruit

b. Crude extract of Bromelain from fruit and sodium meta bisulphite

c. Crude extract of Bromelain from fruit $(10 \mathrm{~mL})$ and sodium acetate buffer $\mathrm{pH} 4.5(5 \mathrm{~mL})$

d. Crude extract of Bromelain from peel

e. Crude extract of Bromelain from peel $(10 \mathrm{~mL})$ and sodium carbonate buffer $\mathrm{pH} 9(5 \mathrm{~mL})$

\section{Application of Crude Extract of Bromelain for Unhairing of Cowhide}

The unhairing efficiency of Bromelain crude extract from fruits and peel of the pineapple was studied using cow hide. The enzyme in $\mathrm{pH} 4.5$ which is in sodium acetate buffer used for this study. Two raw skin pieces were collected from the tannery and marked as I (control) and II (experiment) using blade on the flesh side of the skin. For the unhairing process $100 \% \mathrm{w} / \mathrm{v}$ of skin of enzyme extract was added and for the control instead of enzyme $100 \% \mathrm{w} / \mathrm{v}$ of skin distilled water was added. The ease of unhairing was checked after each hour of enzyme treatment and kept in the rotating machine for $6 \mathrm{~h}$. After $6 \mathrm{~h}$ the drum removed from the rotating machine and kept for overnight. Then after $24 \mathrm{~h}$, the hide piece was taken out and checked the ease of hair loosening.

\section{Unhairing (Hair-Loosening) Index Scale (UI)}

The ease of hair loosening from skin was manually checked during the course of unhairing process and it was indexed (UI) on the basis of 1-5 scale and then transformed into \% unhairing efficiency as shown in Table 2 (Sivakumar et al., 2012).

\section{Results and Discussion}

The juice from both fruit and peel of the pineapple was extracted, which contains the cysteine protease Bromelain. The crude extract of Bromelain was separated from the juice after filteration and centrifugation. Then crude extract was stored at $4^{\circ} \mathrm{C}$ for further studies.

\section{The Enzyme Activity Assay for Crude Extract of Bromelain}

The activity of crude extract of Bromelain from both peel and fruit were studied using casein as substrate. The activity of crude Bromelain enzyme from fruit was found to be $4.71 \mathrm{U} \mathrm{mL}^{-1}$ of enzyme and from peel was found to be $4.52 \mathrm{U} \mathrm{mL}^{-1}$ of enzyme as calculated from the standard graph for tyrosine.

\section{Standard Graph Curve}

The slope of the standard curve drawn between Tyrosine $(\mu \mathrm{g} / \mathrm{mL})$ Vs Absorbance value at $280 \mathrm{~nm}$ was found to be 0.0082 as shown in Fig. 2.

\section{Effect of pH on Enzyme Activity}

The enzyme activity assay as described above was done at neutral $\mathrm{pH}$. However, the effect of $\mathrm{pH}$ on the activity of crude extract of Bromelain was studied in the range of 3.5-7 by using casein as substrate. The results show that the maximum enzyme activity of Bromelain from fruit was observed at $\mathrm{pH}-4.5$ and minimum at $\mathrm{pH}-7$ (Fig. 3). Three sets of experiments were performed for each $\mathrm{pH}$ and average standard deviation value is calculated as 0.04 . The maximum activity of Bromelain enzyme was found to be at $\mathrm{pH}-4.5$ with 4.429 Units $\mathrm{mL}^{-1}$ of enzyme and minimum $\mathrm{pH}-7$ with $0.593 \mathrm{U} \mathrm{mL}^{-1}$.

\section{Effect of Preservatives on Enzyme Activity}

The earlier experiments (section 3.1. and 3.2) were carried out without any preservatives. However, the effects of preservatives on the activity of crude extract of Bromelain were studied using sodium benzoate and sodium metabisulphite and also without preservative as shown in Table 1. This experiment was carried out at optimum pH-4.5 as per the section 3.2. Sodium acetate buffer ( $\mathrm{pH} 4.5)$ was used for the assay. The average standard deviation value for different experiments is found to be 0.06 . The results show that activity of the enzyme was reduced after adding the preservatives to the crude extract of Bromelain compared to the enzyme without preservative as shown in Fig. 4. However, less reduction in activity by using sodium metabisulphite as compared to sodium benzoate. By using sodium benzoate $0.5 \%$ the activity of enzyme is increasing compared to $1 \%$ of sodium benzoate this shows that the concentration of preservatives have role in the enzyme activity.

\section{Kinetic Studies}

Earlier experiments were carried out for fixed time period, whereas, the effect of reaction time between enzyme and the substrate is very important has also been studied. The activity of crude extract of Bromelain was studied after 10, 20,30, 40,50,60, 120 and $180 \mathrm{~min}$ after incubation with substrate. Two sets of experiments were performed for each time period and average standard deviation value is calculated as 0.05 . The results shows that there was an increase in the activity from 10 to $40 \mathrm{~min}$ of incubation and subsequently follows a steady state as shown in Fig. 5. The product formed by enzyme activity on substrate also depends on time of enzyme reaction and increase with the time till it reaches minimum time required for the reaction. Hence, from the results, 40 min could be a optimum time for the enzyme activity under the given process conditions. 


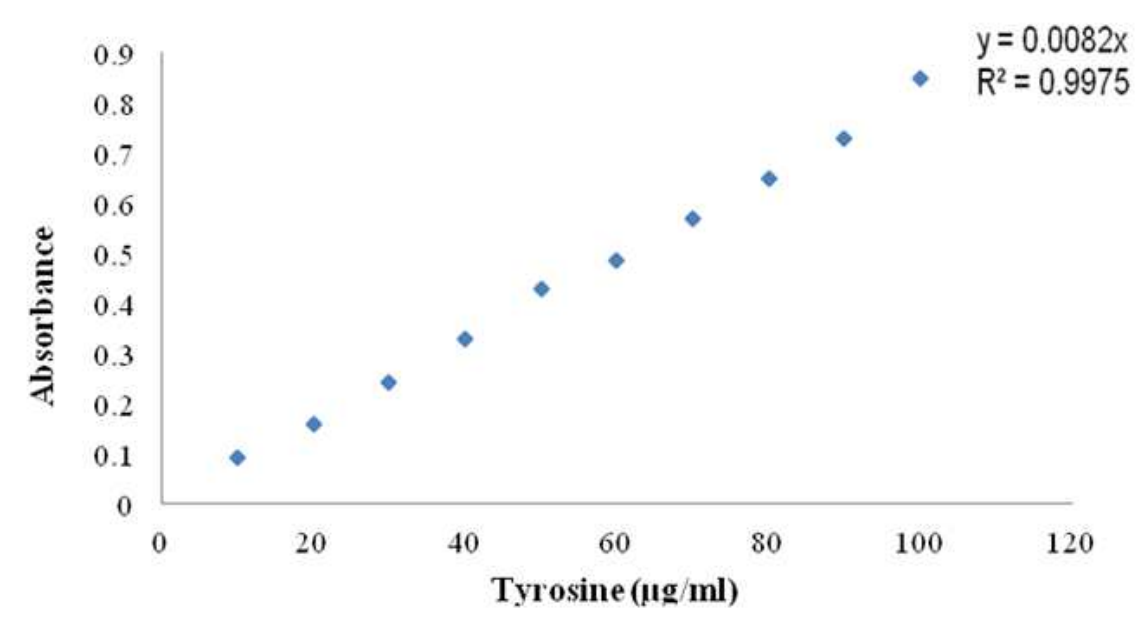

Fig. 2. Standard graph for enzyme Activity assay

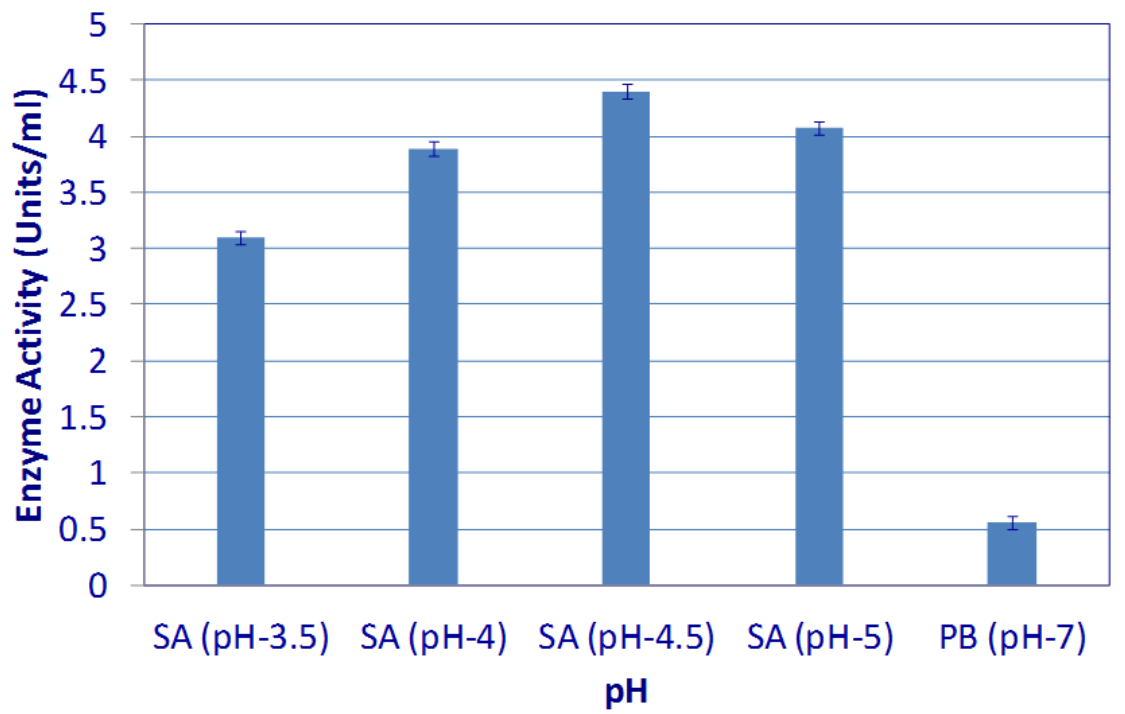

Fig. 3. Effect of $\mathrm{pH}$ on the activity of crude extract of bromelain using Sodium Acetate (SA) and Phosphate Buffe (PB)

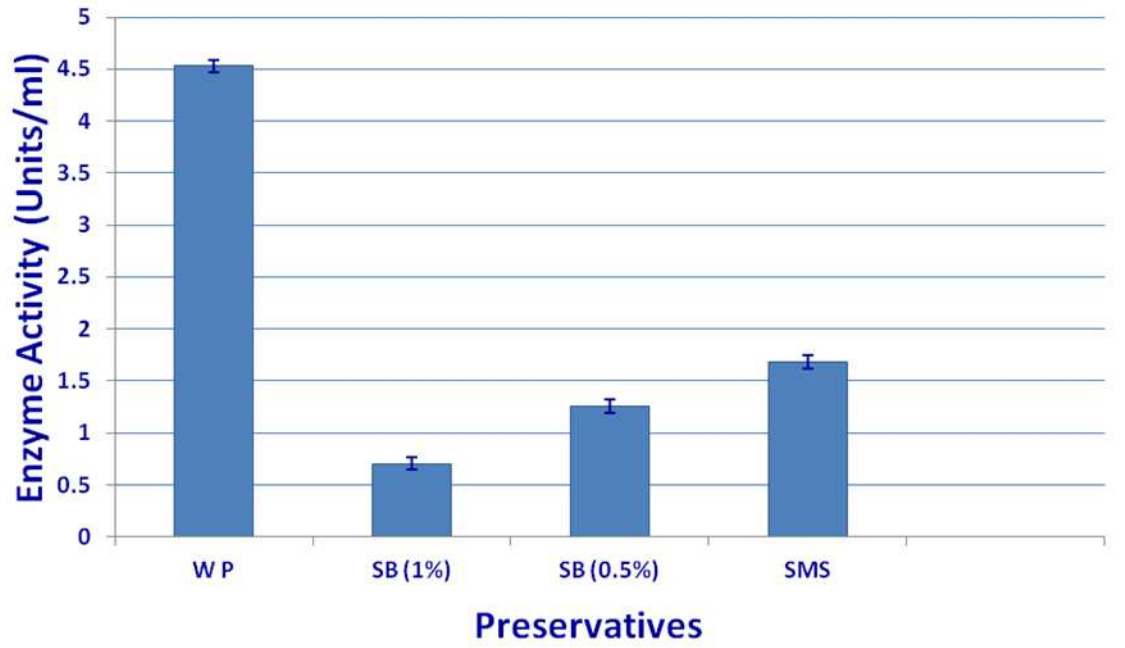

Fig. 4. Effect of preservatives on the activity of crude extract of bromelain 


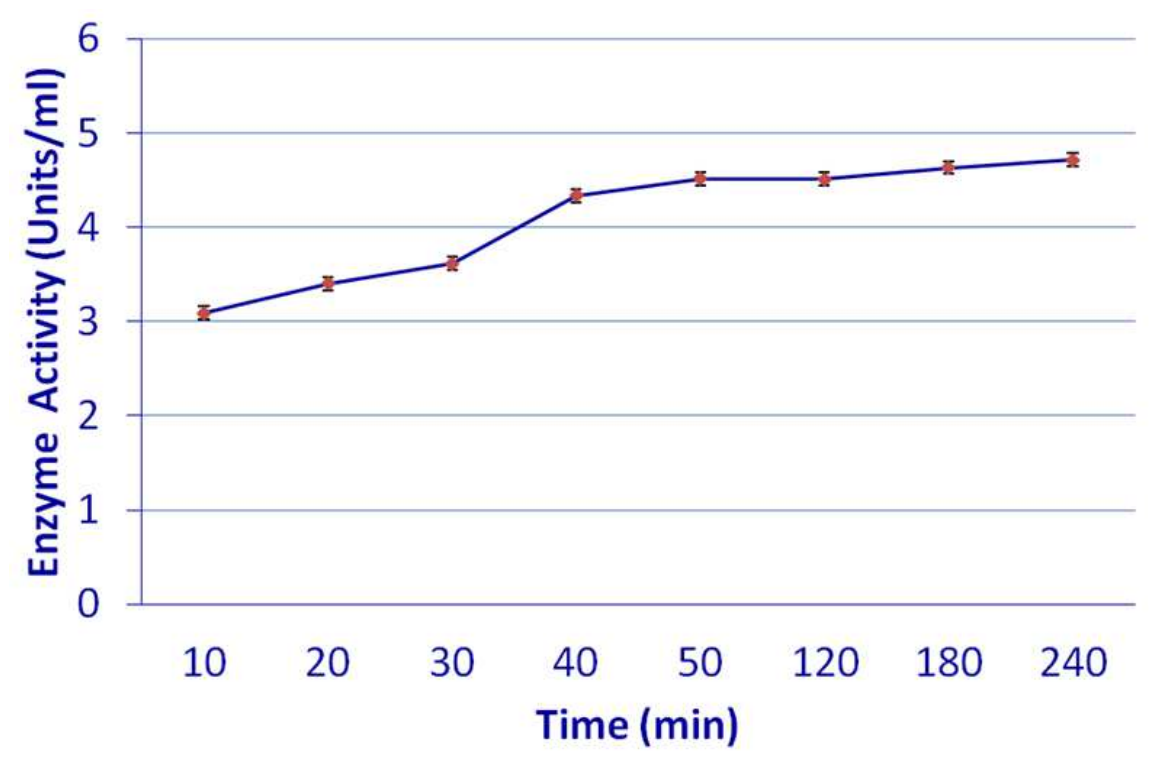

Fig. 5. Kinetics of crude bromelain after incubating with substrate at different time intervals

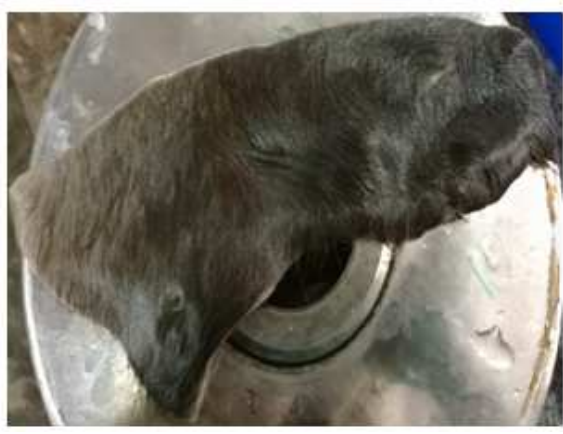

(a)

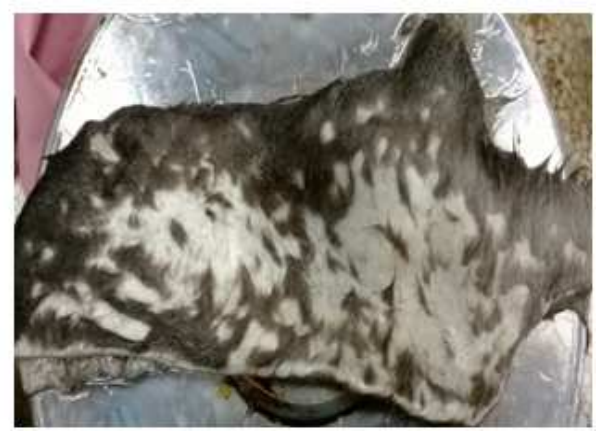

(b)

Fig. 6. Activity of crude extract of bromelain on cow skin, (a) and (b) shows the control experiment before and after treatment with bromelain

Table 1 . The effect of preservatives and buffers on the stability in the activity of crude bromelain enzyme

\begin{tabular}{|c|c|c|c|c|c|}
\hline & \multicolumn{5}{|c|}{ Enzyme activity $(\mathrm{U} / \mathrm{mL})$} \\
\hline & Day 0 & Day 2 & Day 4 & Day 6 & Day 8 \\
\hline Crude extract from fruit + sodium meta bisulphite & $1.68 \pm 0.06$ & $1.32 \pm 0.06$ & $1.18 \pm 0.06$ & $0.92 \pm 0.06$ & $0.49 \pm 0.06$ \\
\hline Crude extract from fruit & 4.28 & 3.79 & 3.12 & 2.75 & 2.23 \\
\hline Crude extract from fruit + sodium acetate buffer $(\mathrm{pH} 4.5)$ & 4.12 & 3.56 & 2.98 & 2.49 & 2.15 \\
\hline Crude extract from peel + sodium carbonate buffer ( $\mathrm{pH} 9)$ & 3.35 & 2.98 & 2.65 & 2.12 & 1.58 \\
\hline Crude extract from peel & 4.02 & 3.76 & 3.34 & 2.45 & 2.11 \\
\hline Standard deviation & \multicolumn{5}{|c|}{ Average $\sigma=0.06$} \\
\hline
\end{tabular}

Table 2. Unhairing index (UI) scale based on ease of hair loosening

\begin{tabular}{ll}
\hline UI scale $(\%$ efficancy) & Hair-loosening ease \\
\hline $1(1-20)$ & No loosening \\
$2(21-40)$ & Moderate loosening \\
$3(41-60)$ & Good loosening \\
$4(61-80)$ & Very good loosening \\
$5(81-100)$ & Excellent loosening \\
\hline
\end{tabular}

\section{Stability of the Crude Bromelain Enzyme Extract}

The stability of the crude extract was studied in alternate days for one week. The results show that the activity of the Bromelain is reducing on alternate days. The colour of the enzyme changed to brown colour and become turbid. Table 1 shows the activity of crude extract of Bromelain on alternate days. 


\section{Application of Crude Extract of Bromelain for} Unhairing of Cowhide

After $24 \mathrm{~h}$ of enzyme treatment provided good loosening of hairs have removed from the skin as shown in Fig. 6. The remaining hairs were found to be moderately loosened as shown in Table 2. Even though, from the discussion above section, enzyme reaction could be completed within $1 \mathrm{~h}$ time, more time is required in the case of treatment of skin in leather processing. The reason could be due to more time taken for the enzyme diffusion through the skin matrix and reaching the substrate. In addition, our future work would be towards production of Bromelain enzyme through solid state fermentation using in order to apply this method in leather industry effectively in solid powder form. In addition, combination of other enzymes and effect of enzyme activity at different weather conditions such as high temperatures during summer would also be studied.

\section{Conclusion}

The objective of the present study is to perform extraction and separation of Bromelain enzyme from the pineapple fruit material and finding out optimum conditions for application in beam house operation in leather processing. For this purpose experiments such as enzyme activity assay for crude extract of Bromelain, effect of $\mathrm{pH}$ on enzyme activity, effect of preservatives on enzyme activity, Kinetic studies on activity, stability of the crude Bromelain enzyme extract and application of crude extract of Bromelain for unhairing of cowhide have been performed. The results indicated that the activity of crude Bromelain enzyme from fruit was found to be $4.71 \mathrm{U} \mathrm{mL}^{-1}$, maximum activity $\left(4.429 \mathrm{U} \mathrm{mL}^{-1}\right)$ of enzyme was found to be at $\mathrm{pH}-4.5$, less reduction in activity by using sodium metabisulphite, kinetic studies indicate optimum enzyme activity time of $40 \mathrm{~min}$ and use of Bromelain enzyme provided good loosening of hairs at $24 \mathrm{~h}$ of treatment. The complete removal of hair at a shorter duration with different weather conditions would be addressed as our future work.

\section{Acknowledgement}

The authors would like to acknowledge CSIR-Central Leather Research Institute for the support.

\section{Funding Information}

CSIR-CLRI In-house project.

\section{Author's Contributions}

Resmi Mohan: Conducting experimental work.
Venkatasubramanian Sivakumar: Experimental design and execution

Thirumalaisamy Rangasamy: Analysis and quality control.

Chellappa Muralidharan: Conception and interpretation of data.

\section{Ethics}

This article is original and contains unpublished material. The corresponding author confirms that all of the other authors have read and approved the manuscript and no ethical issues involved.

\section{References}

Babu, B.R., N.K. Rastogi and K.S.M.S. Raghava rao, 2008. Liquid-liquid extraction of bromelain and polyphenol oxidase using aqueous two-phase system. Chem. Eng. Process Process. Intensif., 47: 83-89. DOI: 10.1016/j.cep.2007.08.006

Batkin, S., S.J. Taussig and J. Szekerczes, 1988. Antimetastatic effect of bromelain with or without its proteolytic and anticoagulant activity. J. Cancer Res. Clin. Oncol., 114: 507-508.

DOI: $10.1007 / \mathrm{BF} 00391501$

Bhattacharyya, B.K., 2008. Bromelain: An overview. Natural Product Radiance, 7: 359-363.

Gautam, S.S., S.K. Mishra, V. Dash, A.K. Goyal and G. Rath, 2010. Comparative study of extraction, purification and estimation of bromelain from stem and fruit of pineapple plant. Thai. J. Pharm. Sci., 34: 67-76.

Hale, L.P., P.K. Greer and G.D. Sempowski, 2002. Bromelain treatment alters leukocyte expression of cell surface molecules involved in cellular adhesion and activation. Clin. Immunol., 104: 183-190. DOI: $10.1006 / \mathrm{clim} .2002 .5254$

Hale, L.P., P.K. Greer, C.T. Trinh and M.R. Gottfried, 2005. Treatment with oral bromelain decreases colonic inflammation in the IL-10-deficient murine model of inflammatory bowel disease. Clin. Immunol., 116: 135-142.

DOI: $10.1016 /$ j.clim.2005.04.011

Harrach, T., K. Eckert, H.R. Maurer, I. Machleidt and W. Machleidt et al., 1998. Isolation and characterization of two forms of an acidic bromelain stem proteinase. J. Protein Chem., 17: 351-361. DOI: 10.1023/A:1022507316434

Heinicke, R.M. and W.A. Gortner, 1957. Stem bromelain-a new protease preparation from pineapple plants. Econ. Bot., 11: 225-234. DOI: $10.1007 / \mathrm{BF} 02860437$

Klaue, P., G. Dilbert and G. Hinke, 1979. Bromelain: Biochemistry, pharmacology and medical use. Cell Mol. Life Sci., 58: 1234-1245. PMID: 11577981 
Livio, M., G.D. Gaetano and M.B. Donati, 1978. Effect of bromelain of fibrinogen level, protrombin complex and platelet aggregation in the rat-a preliminary report. Drugs Expt. Clin. Res., 4: 49-53.

Lozano-de-Gonzales, P.G., D.M. Barrett, R.E. Wrolstad and R.W. Durst, 1993. Enzymatic browning inhibited in fresh and dried apple rings by pineapple juice. J. Food Sci., 58: 399-404. DOI: $10.1111 / \mathrm{j} .1365-2621.1993 . t b 04284 . \mathrm{x}$

Ludvik, J., 1997. Study on the scope for decrease of pollution load in leather processing UNIDO manual on assistance in pollution control I the tanning industry in South East Asia.

Mariappan, M., 1997. Environmental protection initiatives in Indian tanneries-a perspective view. Proceedings 30th LERIG, a National Conference, (LNC' 97), CLRI, Chennai, pp: 151-161.

Maurer, H.R., 2001. Bromelain: Biochemistry, pharmacology and medical use. Cell. Mol. Life Sci., 58: 1234-1245. DOI: 10.1007/PL00000936

Metzig, C., E. Grabowska, K. Eckert, K. Rehse and H.R. Maurer, 1999. Bromelain proteases reduce human platelet aggregation in vitro, adhesion to bovine endothelial cells and thrombus formation in rat vessels in vivo. In vivo., 13: 7-12. PMID: 10218125

Meza, J., P. Lozano-de-Gonzales, A. Anzaldua-Morales, J.V. Torres and J. Jimenes, 1995. Addition of pineapple juice for the prevention of discoloration and textural changes of apple slices. Institute of Food Technologists Annual Meeting, Book of Abstracts.
Mohapatra, V.M. Rao and M. Ranjan, 2013. Comparative study of the increased production and characterization of Bromelain from the peel, pulp and stem pineapple (Anannus commas). Int. J. Adv. Res. Technol., 2: 249-279.

Murachi, T. and H. Neurath, 1960. Fractionation and specificity studies on stem bromelain. J. Biol. Chem., 235: 99-107. PMID: 14425299

Neubauer, R.A., 1961. A plant protease for potentiation of and possible replacement of antibiotics. Exp. Med. Surg., 19: 143-160. PMID: 14479142

Ramasami, T., 2001. Approach towards a unified theory for tanning: Wilson's dream. J. Am. Leather Chem. Assoc., 96: 290-304.

Renzini, G. and M. Varego, 1972. The absorption of tetracyclin in conbination with bromelain by oral application. Arzneim-Forsch, 22: 410-412.

Seltzer, A.P., 1964. A double blind study of bromelain in the treatment of edema and ecchymoses following surgical and non-surgical trauma to the face. Eye Ear Nose Throat Monthly, 43: 54-57.

Sivakumar, V., D. Kumar, R. Kumar and R. Kumar, 2012. Leather bioprocess intensification: Ultrasound assisted novel enzymatic hair-loosening system for leather processing. Int. J. Biotechnol., 11: 326-329.

Walsh, G., 2002. Proteins: Biochemistry and Biotechnology. 1st Edn., John Wiley and Sons London, Chichester, ISBN-10: 0471899070, pp: 547. 